\title{
THE RELATIONSHIP OF KNOWLEDGE, EXPOSURE TO SUNLIGHT, AND CALCIUM INTAKE WITH THE RISK OF OSTEOPOROSIS
}

\author{
Erliza Anggraini Firdaus ${ }^{1}$, Bambang Wirjatmadi ${ }^{2}$ \\ ${ }^{1}$ Study Program of Public Health, Faculty of Public Health, Airlangga University, Surabaya, Indonesia \\ ${ }^{2}$ Department of Health Nutrition, Faculty of Public Health, Airlangga University, Surabaya, Indonesia \\ Correspondence Address: Erliza Anggraini Firdaus \\ Email: Erlizafirdaus9@gmail.com
}

\begin{abstract}
Osteoporosis is a bone disease causing decreased bone density. It often occurs to elderly women. At the age of 5080 years, $23 \%$ Indonesian women were at risk of osteoporosis, and this number would increase to $53 \%$ at the age of 70-80 years. This study aimed to identify the relationship of knowledge, calcium intake and exposure to sunlight habits with the risk of osteoporosis. This study used a cross-sectional design involed 26 members of the osteoporosis gymnastic group who had a low and high risk of osteoporosis. Data of food consumption were retrieved from 24-hour food recall. The chi-square analysis shows knowledge level had a relationship with risk of osteoporosis $(\mathrm{p}=0.047)$. Exposure to sunlight $(\mathrm{p}=0.437)$ and calcium intake $(\mathrm{p}=0.187)$ had a relationship with the risk of osteoporosis. It can be concluded that the level of knowledge had a significant relationship with risk of osteoporosis. Knowledge variable is important to show the community mindset about the dangers and risks of osteoporosis. Therefore, education about osteoporosis is required.
\end{abstract}

Keywords: osteoporosis, knowledge, calcium intake, exposure to sunlight habits.

\begin{abstract}
ABSTRAK
Osteoporosis merupakan penyakit pada tulang yang ditandai dengan penurunan kepadatan tulang. Osteoporosis sering kita jumpai pada wanita lanjut usia atau lansia. Di usia 50 - 80 tahun wanita Indonesia berisiko osteoporosis sebesar $23 \%$ dan akan meningkat menjadi 53\% pada usia 70 - 80 tahun. Tujuan dari penelitian ini adalah mempelajari hubungan pengetahuan dengan asupan kalsium dan kegiatan berjemur pada risiko osteoporosis. Penelitian ini termasuk jenis penelitian yang menggunakan rancangan studi cross sectional. Sampel penelitian ini adalah anggota kelompok senam osteoporosis yang memiliki risiko rendah dan tinggi terkena osteoporosis dengan jumlah 26 orang. Data Konsumsi pangan diperoleh melalui food recall 24 jam. Hubungan antara variabel dengan analisis Chi Square Tingkat pengetahuan dengan risiko osteoporosis $p=0,047$. Kebiasaan berjemur dengan risiko osteoporosis $p=0,437$ dan asupan kalsium pada resiko osteoporosis $p=$ 0,187. Sehingga dapat disimpulkan bahwa tingkat pengetahuan yang memiliki hubungan signifikan terhadap risiko osteoporosis. Faktor pengetahuan sangat penting untuk menunjukkan pola pikir masyarakat mengenai bahaya dan risiko osteoporosis. Dan pemberian edukasi tentang osteoporosis sangat di perlukan.
\end{abstract}

Kata Kunci : osteoporosis, pengetahuan, asupan kalsium dan kegiatan berjemur

\section{INTRODUCTION}

Osteoporosis is a bone disease which reduces bone density. Decreased bone density occurs due to lower calcium levels. Osteoporosis is often called a "silent disease" because it does not cause symptoms apparent to osteoporosis sufferers (Sefrina, 2015). It often occurs to people in middle ages and above, especially women. Osteoporosis can cause disability and social, psychological, and physical problems that interfere someone's health status (Cembrowicz, 2007).

According to the World Health Organization (WHO), there have been 200 million people suffering from osteoporosis worldwide. This number will increase every year. In Indonesia, the Indonesian Ministry of Health stated that the proportion of Indonesians at risk of osteoporosis was $19.7 \%$ in 2016 and would continue 
increasing each year. Further, it was stated that two out of five people in Indonesia were at risk of suffering from osteoporosis. At the age of 50-80 years, $23 \%$ Indonesian women were at risk of osteoporosis, and the proportion would increase to $53 \%$ at the age of 70-80 years (Sefrina, 2015). According to Pranoto (c2009) the Indonesian population had a life expectancy of 64.71 years (1995-2000) and 67.68 years (20002005). With the increasing age, the risk of osteoporosis will increase. Five Indonesian provinces, such as South Sumatra $(27.7 \%)$, Central Java (24.02\%), Yogyakarta (23.5 $\%)$, North Sumara (22.82\%), East Java $(21.42 \%)$ and East Kalimantan $(10.5 \%)$ had a higher risk of osteoporosis.

Muchtadi (2009) mentions the rate of bone formation may be normal, but there will be an acceleration of bone resorption causing a decrease in bone mass. Bone resorption can maintain calcium levels in the blood. When people consumed foods with low calcium levels, they are more likely to suffer from osteoporosis. Some risk factors that can increase the incidence of osteoporosis include heredity, low intake of calcium and vitamin D3, smoking, lack of sun exposure (Setiati, 2008). Further, these factors involve alcohol consumption, fizzy and excessive caffeine consumption, lack of physical activity and exercise, menaoupose, chronic diseases and longduration drug intake (Sefrina, 2015).

Calcium and phosphate play an important role in bone formation. Insufficient calcium intake will lead to abnormal formation of bone and its tissue. Calcium can maintainbone tissue during adulthood, especially for the elderly (Fatmah, 2010) and bone density. Other nutrients that play a role in the bone formation include vitamin $\mathrm{D}$, vitamin $\mathrm{C}$, phosphorus, magnesium, and zinc (Sefrina, 2015).

With the overview of osteoporosis incidence, this study aimed to identify the relationship of knowledge, calcium intake and exposure to sunlight with the risk of osteoporosis.

\section{METHODS}

This study was a comparativeobservational study using a cross-sectional design. The study's population was members of the osteoporosis gymnastics group at Dr. Soetomo District General Hospital, Surabaya. The group was then divided into two sub-groups as the research samples.Group I were the members of the osteoporosis group with low risk of osteoporosis, while Group II consisted of members with high risk of osteoporosis. This study employed a simple random sampling technique to collect 26 female respondents. This study was conducted in the parking lot of the Medical Rehabilitation Installation, Dr. Soetomo District General Hospital Surabaya from October 2016 - January 2017.

To collect primary data, this study used questionnaires given to the respondents to identify their knowledge about osteoporosis, calcium intake, and exposure to sunlight. Further, it utilized the data of monitored food consumption from a 24-hour Food Recall. Meanwhile, this study obtained secondary data from the description and profile of Dr. Soetomo District General Hospital, Surabaya.

The level of knowledge was categorized into three:low $(<60 \%)$, medium $(60 \%-80 \%)$, and high $(>90 \%)$. Potassium consumption level was divided into two: less $(\leq 1200 \mathrm{mg} /$ day) and sufficient $(\geq 1200$ $\mathrm{mg}$ /day) (Andriani, 2012). While levels of exposure to sunlight were categorized into two: enough (10-15 minutes per day) and less ( $<15$ minutes per day) (Marmi, 2013).

Data analysis were carried out in 2 ways: descriptive and analytical analyses. Descriptive analysis presented the results in a frequency distribution table. Chi-square analysis was used to find out the relationship of knowledge, calcium intake, and exposure to sunlight with the risk of osteoporosis $(\alpha=0.05)$. 


\section{RESULTS}

Table 1 shows 12 respondents at low risk of osteoporosis were aged 50-60 years $(92.3 \%)$ and 6 of them with high risk of osteoporosis $(46.2 \%)$ were at the age of 61 70 years. Eight respondents with low risk group had a high school education, and five respondents with high risk had a junior high school education. Mostly, the respondents were housewives $(53.8 \%)$.

Education may affect calcium intake. It lies on the argument that says highly educated elderly will plan a healthy and nutritious diet for himself and his family to meet his family's nutritional needs. According to Notoatmodjo (2011), knowledge is the result of knowing that occurs after people sense a certain object.

Table 1. Characteristics of respondents of osteoporosis gymnastics group at dr. soetomo district general hospital in 2016.

\begin{tabular}{lcccc}
\hline \multirow{2}{*}{ Characteristics } & \multicolumn{2}{c}{$\begin{array}{c}\text { Row } \\
\text { Risk }\end{array}$} & \multicolumn{2}{c}{ High Risk } \\
\cline { 2 - 5 } n & \% & n & \% \\
\hline Age & & & & \\
$50-60$ Years & 12 & 92.3 & 5 & 38.5 \\
61-70 Years & 1 & 7.7 & 6 & 46.2 \\
$>70$ Years & - & - & 2 & 15.3 \\
\hline Total & 13 & 100 & 13 & 100 \\
\hline Education & & & & \\
Elementary & 1 & 7.7 & 1 & 7.7 \\
Junior High & - & - & 5 & 38.5 \\
High school & 8 & 61.5 & 4 & 30.8 \\
Diploma & 4 & 30.8 & 1 & 7.7 \\
Bachelors & - & - & 2 & 15.3 \\
\hline Total & 13 & 100 & 13 & 100 \\
\hline Job & & & & \\
Housewife & 4 & 30.8 & 7 & 53.8 \\
Retiree & 5 & 38.5 & 6 & 46.2 \\
Civil servant & 2 & 15.3 & - & - \\
Private & & & & \\
employee & 1 & 7.7 & - & - \\
Entrepreneur & 1 & 7.7 & - & - \\
\hline Total & 13 & 100 & 13 & 100 \\
\hline
\end{tabular}

Table 2. Relationship between knowledge levels and risk of osteoporosis among the respondents.

\begin{tabular}{lcccc}
\hline \multirow{2}{*}{$\begin{array}{c}\text { Level } \\
\text { Knowledge }\end{array}$} & \multicolumn{2}{c}{ Low Risk } & \multicolumn{2}{c}{ High Risk } \\
\cline { 2 - 5 } Low & $\mathbf{n}$ & $\boldsymbol{\%}$ & $\mathbf{n}$ & $\boldsymbol{\%}$ \\
\hline Medium & - & - & 2 & 15.3 \\
\hline High & 7 & 53.8 & 1 & 7.7 \\
\hline Total & 13 & 100 & 13 & 100 \\
\hline $\mathbf{P}$ & & 0.047 & & \\
\hline
\end{tabular}

The analysis informs us that most of the respondents had high school and junior high school education. They mostly had moderate knowledge about osteoporosis. The community knowledge and education level may suggest mindset about the dangers and symptoms of osteoporosis, and the state of work that might make them overlook their health problems. The result shows half of the respondents with low risk had a moderate level of knowledge $(53.8 \%)$. While, 10 respondents with high risk had a high level of knowledge (77\%).

Patterns of food consumption from one person to another can be different due to different levels of knowledge. Likewise, the elderly who have osteoporosis factors tend to have different food consumption patterns following their level of knowledge. Someone who is knowledgable tend to choose better quality foods.

Generally, calcium is necessary for the bone development. Osteoblasts add and store calcium in bones, while osteoclasts break down and excrete calcium in bones In particular cases, when the body lacks calcium, calcium in the bones will be released to meet the body's needs, thus causing porous bones (Tandra, 2009). Old people generally lack calcium which should at $1000 \mathrm{mg}$ among people aged $19-50$ years. People more than 51 years old even need higher calcium intakes at $1200 \mathrm{mg}$ (Andriani, 2012). Someone's physical health will decrease in older ages. As a result, it may cause psychological and 
social physical function disorders which can further lead to dependency on others (Andriani, 2012).

Table 3. Relationship between calcium intake and risk of osteoporosis among the respondents.

\begin{tabular}{lcccc}
\hline \multirow{2}{*}{ Calcium Intake } & \multicolumn{2}{c}{ Low Risk } & \multicolumn{2}{c}{$\begin{array}{c}\text { High } \\
\text { Risk }\end{array}$} \\
\cline { 2 - 5 } & $\mathbf{n}$ & $\%$ & n & $\%$ \\
\hline $\begin{array}{l}\text { Less } \\
<1200 \mathrm{mg}\end{array}$ & 8 & 61.5 & 6 & 46.2 \\
\hline $\begin{array}{l}\text { Enough }>1200 \\
\mathrm{mg}\end{array}$ & 5 & 38.5 & 7 & 53.8 \\
\hline Total & 13 & 100 & 13 & 100 \\
\hline $\mathbf{P}$ & & 0.187 & & \\
\hline
\end{tabular}

In the low risk group, 8 respondents (61.5\%) had less than $1200 \mathrm{mg}$ calcium intake per day. Seven respondents $(53.8 \%)$ with high risk had a sufficient calcium intake at > $1200 \mathrm{mg}$ per day.

Table 4. Relationship between level of exposure to sunlight and risk of osteoporosis among the respondents.

\begin{tabular}{lcccc}
\hline \multicolumn{1}{c}{$\begin{array}{c}\text { Level of } \\
\text { Exposure to }\end{array}$} & \multicolumn{2}{c}{ Low Risk } & \multicolumn{2}{c}{ High Risk } \\
\cline { 2 - 5 } \multicolumn{1}{c}{ Sunlight } & n & \% & n & $\%$ \\
\hline Enough & 8 & 61.5 & 6 & 46.2 \\
\hline Not enough & 5 & 38.5 & 7 & 53.8 \\
\hline Total & 13 & 100 & 13 & 100 \\
\hline $\boldsymbol{P}$ & & 0.431 & & \\
\hline
\end{tabular}

Moreover, osteoporosis can be prevented if people receive enough vitamin $\mathrm{D}$ which comes from sunlight. People need about ten-to-fifteen-minute sunlight exposure every day (Marmi, 2013). The intensity of UVB (short ultraviolet waves) sunlight is low at 07.00 AM and increases in the following hours. At $11.00 \mathrm{AM}$, this intensity is relatively stable and high until 14.00 PM. At 16.00 PM, it reaches the same intensity as at 07.00 AM. Exposure to low intensity of sunlight can facilitate vitamin D intake (Setiati, 2008). The result explains eight respondents with low risk $(61.5 \%)$ had sufficient exposure to sunlight, while 7 respondents with high risk $(53.8 \%)$ had inadequate exposure to sunlight.

\section{DISCUSSION}

The members of osteoporosis gymnastics group at Dr. Soetomo District General Hospital Surabaya mostly had a junior high school, high school, and diploma education. Besides, they had moderate knowledge about osteoporosis.

Furthermore, food consumption that varies among people may be due to different levels of knowledge. Likewise, the elderly could have different food consumption patterns since exposure to information they obtained might be different too.

People aged 19-50 years ideally need $1000 \mathrm{mg}$ calcium, while those more than 51 years old should have $1200 \mathrm{mg}$ calcium intake (Andriani, 2012). Another mineral that plays an important role in bones is phosphorus. Consuming less or excessive food is also not good for the body. Food consumption discussed in this study explains about types and amount of daily food consumption, as well as characteristics of the food consumers (Andriani, 2012).

This study reveals that the level of knowledge had a significant relationship with the risk of osteoporosis. Knowledge can lead to an action, activity or behavior (Kusumawati 2014). Elderly with good knowledge tend to maintain health condition every day. According to Notoatmodjo (2011), before adopting new behaviors, someone will experience a sequential process starting from awareness (awareness), in which they realize a stimulus (object). In other words, knowledge is necessary for investing healthy behavior. Some vulnerable groups with high risks of osteoporosis were those who were menopause and, smokers. Also, those were aged 30 to 40 years who had heredity, lack of exercise, history of certain drug consumption, and low intake of calcium and vitamin D. To prevent 
osteoporosis, knowledge is the key factor that might trigger someone to consume healthy foods for bones, regulate a healthy lifestyle, and exercise regularly and support bone health.

Calcium intake in the elderly is very important for bone strength to avoid osteoporosis. If calcium intake in bone decreases, bone density will decrease faster thereby leading to greater osteoporosis risks. Furthermore, vitamin D plays an important role in the process of calcium absorption in the body (Sefrina, 2015). Older people who have more calcium and more exposure to sunlight will be less at risk of osteoporosis.

Every day the respondents consumed carbohydrates derived from whole grains (rice). Elderly are recommended to consume less simple sugars and replace them with complex carbohydrates contained in nuts and seeds as a source of energy and a source of fiber (Marmi, 2013). This result explains that most respondents consumed carbohydrates derived from noodles once a month (sometimes).Vegetable and animal protein is required to fulfill $10 \%$ of the total calorie needs per day (Andriani, 2012). However, the repsondents rarely consumed animal protein. This study shows the respondents consumed meat, eggs, and other animal protein food twice a week. Daily consumption of vegetables and fruits with high fiber was good enough. However, excessive consumption of fiber may cause minerals and other nutrients to be absorbed by the fibers, not by the body itself.

Also, milk is important because of its high calcium level is good for bones. This type of food can be an alternative for people aged more than 51 years and requiring 1200 mg calcium intake.

The analysis shows that there was a significant relationship between knowledge and exposure to sunlight. Knowledge can be manifested into actions or attitudes towards health and risk of osteoporosis. Early prevention and treatment can be done through knowledge investment. However, the analysis shows there was no relationship between knowledge and exposure to sunlight. It may be due to the fact that vitamin $\mathrm{D}$ can be absorbed from not only sunlight, but also foods and other supplements such as milk. The result has a relevance with the fact that most of the respondents were retirees who maybe do not work outside and take a moment for being exposed to sunlight in the morning.

This study also reveals that $53.8 \%$ of the respondents had sufficient exposure to sunlight. Most of them already knew the importance of exposure to sunlight since vitamin $D$ generated form sunlight contributes to the bone mineralization process in which the absorption of calcium occurs in the body (Tandra, 2009). A previous meta-analysis study recommends to give high doses of calcium intake (1200 $\mathrm{mg}$ or more) and vitamin D intake (800 mg or more) to prevent osteoporosis (Witjaksono, 2012).

The body needs calcium for metabolic processes. When the body lacks calcium, it will take calcium reserves in the bones. Apart from consuming high-calcium foods, people need to be concerned about vitamin $\mathrm{D}$ deficiency which will impact bone metabolism seriously.

\section{CONCLUSION}

The study's respondents were mostly aged 50-60 years, had high school education, a moderate level of knowledge about osteoporosis, worked as a housewife or retiree, and had enough exposure to sunlight and good food intake. Knowledge had a significant relationship with risk of osteoporosis. Therefore, the hospital needs to further educate the gymnastics group about the risks and dangers of osteoporosis to make them more alert about the issues. The group also needs to be more open to parties or management and willing to express complaints or problems related to their health.

It is also highly recommended that further research could use a larger number 
of samples and more variables to give more representative findings.

\section{REFERENCE}

Andriani, M., Wirajarmadi, B., 2012. Peranan Gizi dalam Siklus Kehupan. Jakarta: Kencana Prenada Media Grup.

Cembrowicz, 2007. Osteoporosis. 2th ed. London : Class publising.

Fatmah, 2010. Gizi usia lanjut. Jakarta: Erlangga.

Kusumawati, D., 2014. Gambaran Tingkat Pengetahuan Lansia Tentang Osteoporosis di Panti Wedha Dharma Bakti Surakarta. Karya Tulis Ilmiah. STIKES PKU Muhammadiyah Surakarta.

Marmi, 2013. Gizi dalam Kesehatan Reproduksi. Yogyakarta: Pustaka Belajar.

Muchtadi, D., 2009. Gizi anti penuaan dini. Bandung: Alfabeta, CV.

Notoatmodjo, S., 2011. Kesehatan Masyarakat. Jakarta : Rineka cipta.

Notoatmodjo, S., 2012. Metodelogi penelitian kesehatan. Jakarta: Rineka cipta.

Pranoto, A., 2009. Osteoporosis secara umum. Diabetes and Nutrition Center, Dr Soetomo HospitalAirlangga University Division of Endocrinology Metabolism, Department of Internal Medicine, Medical Faculty, Airlangga University.

Sefrina, A., 2015. Osteoporosis the silent disease. Yogyakarta : rapha oitpada Publising.

Setiati, S., 2008. Pengaruh Pajanan Sinar Ultraviolet B Bersumber di Sinar Matahari terhadap konsentrasi Vitamin D (25(OH)D) dan Hormon Paratiroit pada perempuan usia lanjut. Jurnal Kesehatan Masyarakat Nasional, 2(4), pp.147 -15 .

Tandra, H., 2009. Segala sesutu yang anda ketahui tentanng osteoporosis mengenal, mengatasi, dan mencegah tulang keropos. Jakarta: PT. Gramedia Pustaka Utama.

Witjaksono, F., 2012. Nutrisi pada Osteoporosis. Jakarta: RSCM Departemen Gizi FKUI. 